\title{
Tool Wear Performance Investigation of Stellram Indexable Milling Cutter (XDLT09-D41) for Machining Ti-6Al-4V
}

\author{
Saad Nawaz ${ }^{1,2}$, Yu Gang ${ }^{1,2}$, Li Shaoxia ${ }^{1,2}$, He Xiuli ${ }^{1,2}$, Ning Weijian ${ }^{1}$, Zheng Caiyun ${ }^{1}$, Miao Haibin ${ }^{1,2}$ \\ ${ }^{1}$ Institute of Mechanics, Chinese Academy of Sciences, Beijing 100190, China. E-mail: gyu@imech.ac.cn \\ ${ }^{2}$ School of Engineering Science, University of Chinese academy of sciences, Beijing 100490, China.
}

\begin{abstract}
An extensive experimental investigation was carried out to study the performance of Stellram Indexable Milling Cutter (XDLT09-D41), used for rough down milling of Ti-6Al-4V alloy. The machining performance was investigated for small depth of cut under different combinations of the operating parameters; like application of high pressure coolant and their impact in terms of tool wear, tool life, thermal crack, etc. The range of operating parameters were broadened, to get comprehensive results in comparison with previous work. The critical observations of the tool wear were at the tool tip/nose and at the bottom part of tool; where thermal deformations were most likely to be propagated with time. It has been noticed that the flank wears were owing to scratching of the cutting chips and diffusion wears were because of high thermal stresses at the bottom of the cutting tool. These findings are in consistent with literature; moreover, the optimum operating parameters were further enhanced to achieve superior performance. Integrated methodology maximized tool life to the moderate speed of $40 \mathrm{~m} . \mathrm{min}^{-1}$, feed rate of $358 \mathrm{~mm} . \mathrm{min}^{-1}$ and depth of cut of $0.8 \mathrm{~mm}$. It is generally concluded that the cutting performance has poor relation with alloy properties compared to the operating conditions.
\end{abstract}

Keywords: Tool Wear, Titanium Alloy, High Coolant Pressure, Cutting Speed, Flank Wear, Tool Life

\section{Acknowledgment}

The authors would like to thanks teachers and labmates for their time to time guidance and techenical support.

\section{References}

[1] NAWAZ, S., XING, L., CHAI, Z. (2014). Performance of Brazed Carbide End Mill Tool for Machining of Ti6Al4V, Applied Mechanics and Materials, Vol. 541-542, pp 363-367.

[2] MYERS, J. R., BOMBERGER, H. B., FORCES, F. H., MATER, J. (1984). Journal of Materials Processing Technology, Vol. 36, No. 10, pp 50-60.

[3] NAWAZ, S., NAWAZ, Z., WUYI, C. (2012). Computer Added Process Planning: An Integrated Approach towards Manufacturing Sustainability, Science International (Lhr), Vol. 24, No. 1, pp. 11-12.

[4] NAWAZ, S., YU, G., SHAOXIA, L., XIULI, H., ZHANG, Y., HAIBIN, M. (2017). Experimental Investigation of Defocused Focal Plan and its Effect on Hole Profile in Millisecond Percussion Laser Drilling, Science International (Lahore), Vol. 29, No. 1, pp 291-295.

[5] VASILKO, K. (March, 2014). New Experimental Dependence of Machining, Manufacturing Technology, Vol. 14, No. 1, pp $111-116$.

[6] NAPRSTKOVA, N., CAIS, J., STANCEKOVA, D. (March, 2014). Influence of Alsi7Mg0.3 Alloy Modification by $\mathrm{Sb}$ on the Tool Wear, Manufacturing Technology, Vol. 14, No. 1, pp 75-79.

[7] KUNDRAK, J., GYANI, K., DESZPOTH, I. (December 2012). The effect of the borehole diameter on the machining times in hard machining, Manufacturing Technology, Vol. 12, No. 13, pp 144-150.

[8] VASILKO, K., MURCINKOVA, Z. (April 2017). The Proposal How to Make the Basic Machining Technologies - Turning, Milling, Planing - More Productive, Manufacturing Technology, Vol. 17, No. 2, pp 261-267.

[9] SHARIF, S., RAHIM, E. A. (2007). Performance of coated- and uncoated-carbide tools when drilling titanium alloy_Ti-6Al4V, Journal of Materials Processing Technology, Vol. 185, pp 72-76.

[10] SIEKMANN, H. J. (1955). How to Machine Titanium, The Tool Engineer, Vol. 34, pp 78-82.

[11] KOMANDURI, R., REED, Jr. W. R. (1983). Wear, Vol. 92, pp 113-123.

[12] SAKURAI, K., ADICHI, K., OGAWA, K., NIBA, R. (October 13-16, 1991). Astudy on drilling ofTi-6Al-4V by TiN coated drills, Proceedings of the Int. Conf. Recent Advances in Science and Engineering of Light Metals, Sendai, Japan, pp. 803-808. 
[13] FUJISE, K., OHTANI, T. (1998). Machinability of Ti-6Al-4V alloy in drilling with small drill, Proceedings of the Fourth International Conference on Progress of Cutting and Grinding, Urmqi and Torpan, China, October 59, pp. 49-54.

[14] MANTLE, A. L., ASPINWALL, D. K., WOLLENHOFER, O. (1995). Twist drill of gamma titanium aluminade intermetallics, Proceedings of the 12th Conference of the Irish Manufacturing Committee, University College Cork, September 6-8, pp. 229-236.

[15] KING, R. I., VAUGHN, R. L. (1984). A Synoptic Review of High-Speed Machining from Salomon to the Present, High Speed Machining: Presented at the Winter Annual Meeting of ASME, Edited by Komanduri, R., Subramanian, K. and von Turkovich, B.F., New Orleans, Louisiana, pp 1-13.

[16] HARVEY (Ed), P. D. (1982). Engineering Properties of Steel, ASM.

[17] MULLER, C., BLUMKE, R. (2011). Influence of heat treatment and cutting speed on chip segmentation of age hardenable aluminum alloy, Materials Science and Technology, Vol. 17, pp 651-654.

[18] ZLATIN, N., CHRISTOPHER, J. D. (1073). Technical paper of Society of Manufacturing Engineering, Michigan, MR73-909, Vol. 15.

[19] SHAW, M. C. (1971). ISI special report 94. London, pp 1 -9.

[20] BHAUMIK, S. K., DIVAKAR, C., SINGH, A. K. (1995). Machining Ti-6Al4-V alloy with a wBN-cBN composite tool, Materials \& Design, Vol. 16, pp 221-226.

[21] WANG, Z. G., RAHMAN, M., WONG, Y. S. (2005). Tool Wear Characteristics of Binderless CBN Tools Used in High-Speed Milling of Titanium Alloys, Wear, Vol. 258, pp 752-758.

[22] MUSTAFIZUR, R., GANG, Z. (2006). A review on High-speed Machining of Titanium Alloys, JSME international.

[23] UDDIN, M. S., PHAM, B., SARHAN, A., BASAK, A., PRAMANIK, A. (March, 2017). Comparative study between wear of uncoated and TiAlN-coated carbide tools in milling of Ti6Al4V, Advances in Manufacturing, Volume 5, Issue 1, pp 83-91. 